\title{
IMPLEMENTASI MODEL PEMBELAJARAN CLT UNTUK MENINGKATKAN KEMAMPUAN BERBICARA AKTIF BAHASA INGGRIS BERBASIS NILAI-NILAI KARAKTER BERBAHASA
}

\author{
Arif Widagdo \\ Jurusan PGSD, Fakultas Ilmu Pendidikan \\ Universitas Negeri Semarang \\ arifwidagdounnes@gmail.com
}

\begin{abstract}
Abstrak
Berbicara merupakan salah satu keterampilan berbahasa Inggris yang sangat penting dalam komunikasi lisan yang berkualitas dari sisi konten kalimat dan karakter (kesantunan) berbahasa. Penelitian ini berawal dari permasalahan mahasiswa PGSD FIP UNNES (sekitar $70 \%$ ) memiliki kemampuan berbicara (speaking) bahasa Inggris yang masih kurang bagus. Tujuan dari penelitian ini adalah untuk meningkatkan kompetensi active speaking mahasiswa melalui model Communicative Language Teaching (CLT) dalam proses kegiatan pembelajaran mata kuliah bahasa Inggris. Hasil penelitian menunjukkan bahwa penerapan model Communicative Language Teaching dapat meningkatkan kompetensi active speaking mahasiswa dalam proses kegiatan pembelajaran mata kuliah bahasa Inggris di PGSD yang berbasis konservasi nilai-nilai karakter (berbahasa). Indikator active speaking (keaktifan berbicara secara aktif-komunikatif). Dalam proses pembelajaran, keterampilan active speaking menjadi fokus utama penelitian tindakan ini, dimana desain pembelajaran melibatkan empat kompetensi komunikatif yaitu: kompetensi gramatikal, kompetensi sosiolinguistik, kompetensi wacana/discourse, dan kompetensi strategi. Dilihat dari hasil penilaian siklus I ada peningkatan rara-rata kelas. Nilai rata-rata kelas pada pra tindakan yaitu 68,77 pada siklus I meningkat menjadi 76,38. Dan hasil penilaian siklus II menunjukan adanya peningkatan rara-rata kelas yang cukup signifikan, dimana nilai rata-rata kelas pada siklus I yaitu 76,38 pada siklus II meningkat menjadi 82,20.
\end{abstract}

Kata Kunci: Bahasa Inggris, CLT, Active Speaking, Nilai Karakter Berbahasa

\begin{abstract}
Speaking is one of skills in English which very important for spoken communication, content side of sentence and speak in character (politeness). This research start from problem of PGSD student in FIP UNNES (around 70\%) have lack of English skill. The goal of this research is to improve the competence of student' active speaking through communicative languange teaching (CLT) model in learning process of English course. The result show that the implementation of communicative languange. Teaching can improve the competence of student's active speaking in English course of PGSD based on conservation of character value
\end{abstract}


( speak in ). Indicator of active speaking skill become main focus in this action research, where the learning design involving four communicative competencies, they are : grammatical, socialinguistic competence, discourse competence and strategy competence. Seen by the result of cycle I, there is improvement score in class average. Average score on pra treatment is 68,77, on cycle 1 increase become 76,38. And the result of scoring on cycle II shows the is improvement on significant average, where class average score on cycle I is 78,38 on cycle II increase become 82,20

Keywords: English, CLT \& active speaking, character values in language

\section{A. PENDAhULUAN}

Mahasiswa sebagai penerus pembangunan nasional harus dibekali dengan ilmu dan keterampilan yang dapat membuat mereka mampu bersaing di era modern saat ini, salah satunya yaitu dengan kemampuan berbahrasa Inggris yang aktif dan komunikatif, bagus dan bermuatan nilai-nilai karakter berbahasa, karena bahasa Inggris merupakan bahasa Internasiona, yang dipakai oleh lebih dari 100 negara dalam pergaulan internasional.

Pengembangan dan praktik pembelajaran bahasa Inggris berbasis karakter untuk tingkat Sekolah Dasar (SD) di Jawa Tengah dan pada umumnya di Indonesia menjadi tantangan dan tanggungjawab pendidik, termasuk para mahasiswa PGSD sebagai calon guru Sekolah Dasar untuk dapat menyiapkan diri dengan penguasaan bahasa Inggris komunikatif berupa kemampuan berbicara aktif (active speaking) sebagai persiapan diri calon guru yang nantinya akan mengajarkan bahasa Inggris sebagai muatan lokal/extrakurikuler atau yang nantinya akan mengajar menggunakan bahasa Inggris sebagai bahasa pengantar pembelajaran atau English for Instruction atau pun di kelaskelas bilingual di Sekolah Dasar.

Mata kuliah bahasa Inggris di Jurusan Pendidikan Guru Sekolah Dasar (PGSD) FIP UNNES, pada mulanya perkuliahan terfokus pada pengajaran atau penguasaan grammar/structure dengan teori-teori pembelajaran terkait, sehingga pembelajaran bahasa Inggris lebih bersifat pasif dan teacher-centered. Perkuliahan bahasa Inggris difokuskan pada pemahaman struktur bahasa. Strategi perkuliahan yang digunakan di dalam kelas juga kurang mendukung peningkatan keterampilan berbicara aktif 65 MAGISTRA - Volume 9 Nomor 2 Desember 2018 
mahasiswa. Kemudian seiring waktu berjalan, fokus pembelajaran kemudian diarahkan pada pengusaan kompetensi kebahasaan atau Competency-Based English dengan mengintegrasikan Discourse Competence dan Genre Based English. Selanjutnya, pada pembelajaran bahasa Inggris di PGSD, desain pembelajaran mengintegrasikan Competency and Tasks dengan Discourse and Genre-Based English sampai tahun 2011-an, yang menekankan penguasaan empat kompetensi komunikatif yaitu: kompetensi grammatikal, kompetensi sosiolinguistik, kompetensi wacana, dan kompetensi strategi.

Hal-hal yang tersebut di atas mendukung kebutuhan mahasiswa dan tuntutan dunia pendidikan dimasa kini akan kemampuan mengajar di Sekolah Dasar (SD) khususnya SD yang memiliki predikat Sekolah Berstandar Internasional (SBI), atau SD yang menyelenggarakan pembelajaran dengan dua bahasa (bilingual). SBI mewajibkan para gurunya untuk mempunyai kemampuan komunikatif berbahasa Inggris, misalnya bahasa Ingris sebagai bahasa pengantar dalam proses Kegiatan Belajar Mengajar di kelas bilingual.

Prodi Pendidikan Guru Sekolah Dasar (PGSD) Universitas Negeri Semarang (UNNES) memiliki tugas untuk mempersiapkan mahasiswanya sebagai calon guru SD, salah satunya agar mempunyai kemampuan komunikatif berbahasa Inggris yang baik, lisan dan praktik dengan memberikan mata kuliah bahasa Inggris sebagai mata kuliah umum wajib.

Tujuan dari pemberian mata kuliah bahasa Inggris untuk mahasiswa jurusan PGSD adalah untuk memberikan bekal kepada mahasiswa agar dapat meningkatkan keterampilan bahasa Inggris yang berbasis nilai-nilai karakter berbahasa. Selain itu, agar mereka dapat menyampaikan materi dalam bahasa Inggris untuk siswa sekolah dasar seperti pada sekolah yang berstandar internasional ataupun sekolah bilingual.

Keterampilan berbahasa (language skills) mencakup empat keterampilan; yaitu keterampilan membaca (reading skills), mendengarkan (listening skills), menulis (writing skills), dan berbicara (speaking skills), sebagai fokus utama pengajaran bahasa 
Inggris di sekolah. Keterampilan berbahasa tersebut ini harus diajarkan secara proporsional dalam waktu bersamaan. Oleh sebab itu, perlu adanya pembagian waktu secara proporsional dalam perkuliahan bahasa Inggris yang hanya satu semester agar empat keterampilan tersebut dapat merata penekanannya.

Proses pembelajaran di kelas haruslah berkualitas, yang ditandai oleh tiga unsur: (1) tingkat partisipasi dan jenis kegiatan belajar yang dihayati oleh mahasiswa, (2) peran dosen dalam proses belajar mengajar, dan (3) suasana proses belajar. Makin intensif partisipasi mahasiswa dalam kegiatan belajar mengajar, makin tinggi kualitas proses belajar tersebut ${ }^{1}$. Tambahan lagi, tingkat partisipasi yang tinggi dari mahasiswa dalam kegiatan belajar mengajar dapat dicapai apabila mereka memiliki kesempatan untuk secara langsung (1) melakukan berbagai bentuk pengkajian untuk memperoleh pengetahuan dan pemahaman, (2) berlatih berbagai keterampilan kognitif, personal sosial, dan psikomotorik, maupun yang berbentuk sebagai dampak pengiring, dan (3) menghayati berbagai peristiwa sarat nilai baik secara pasif dalam bentuk pengamatan dan pengkajian maupun secara aktif melalui keterlibatan langsung di dalam berbagai kegiatan serta peristiwa pembelajaran. ${ }^{1}$

Dosen sebagai pengelola kelas berperan menentukan tingkat partisipasi mahasiswa dalam proses KBM. Salah satu hal yang berpengaruh pada peran dosen adalah metode mengajar yang digunakannya. Penggunaan metode mengajar akan menentukan corak pembelajaran mahasiswa di dalam kelas. Metode berkaitan dengan pendekatan, rancangan, dan prosedur pengajaran. Pendekatan mencakup dua aspek, yaitu hakikat materi pelajaran dan teori belajar. Rancangan mencakup aspek-aspek seperti tujuan pengajaran, model silabus/kurikulum, jenis dan prosedur kegiatan belajar mengajar (KBM), jenis dan fungsi materi pelajaran, dan peran dosen serta mahasiswa. Sementara itu, prosedur berkenaan dengan teknik-teknik pengajaran yang digunakan oleh dosen dalam pembelajaran di dalam kelas. Ketiga unsur metode tersebut

\footnotetext{
${ }^{1}$ Raka Joni, Pendekatan Cara Belajar Siswa Aktif: Acuan Konseptual Peningkatan Mutu Kegiatan Belajar Mengajar, Jakarta: Konsorsium Ilmu Pendidikan Depdikbud, 2009, hlm. 50
}

67 MAGISTRA - Volume 9 Nomor 2 Desember 2018 
berhubungan secara hierarkis. Pendekatan mendasari rancangan dan rancangan mendasari prosedur pengajaran. Oleh karena itu, pelaksanaan teknik-teknik pengajaran di dalam kelas harus sejalan dengan rancangan dan pendekatan pembelajaran yang dipergunakan.

Dalam kurikulum dan deskripsi mata kuliah dinyatakan bahwa tujuan utama perkuliahan bahasa Inggris adalah: (1) mengembangkan kompetensi berkomunikasi dalam bentuk lisan dan tulis untuk mencapai tingkat literasi internasional, (2) memiliki kesadaran tentang hakikat dan pentingnya bahasa Inggris untuk meningkatkan daya saing bahasa dalam masyarakat global, (3) mengembangkan pemahaman peserta didik tentang keterkaitan antara bahasa dan budaya.

Pembelajaran bahasa Inggris di tingkat sekolah atau di perguruan tinggi pada praktiknya hanya berfokus pada satu atau dua keterampilan saja. Hal ini disebabkan oleh banyak faktor seperti dosen, mahasiswa, fasilitas, lingkungan belajar, pemerintah, dan perangkat pendukung proses belajar mengajar yang lain. Demikian pula, keberhasilan perkuliahan bahasa Inggris di jurusan PGSD FIP UNNES dipengaruhi oleh faktor-faktor tersebut.

Perkuliahan bahasa Inggris di PGSD FIP UNNES lebih menitikberatkan pada elemen struktur (structure). Hal ini tentu kurang sesuai dengan tujuan utama perkuliahan bahasa Inggris di tingkat perguruan tinggi, yaitu mahasiswa diharapkan mampu berkomunikasi aktif secara lisan dan tertulis. Dilihat dari nilai-nilai praktik mahasiswa menunjukkan bahwa kemampuan praktek bahasa Inggris mahasiswa masih rendah (lebih dari 70\%), sehingga perlu adanya pengembangan metode-metode atau teknik-teknik perkuliahan yang tepat dan variatif, karena dengan metode perkuliahan yang monoton, mahasiswa akan semakin tidak tertarik belajar bahasa Inggris. Mahasiswa memerlukan metode perkuliahan yang memungkinkan mereka merasa tertarik dengan bahasa Inggris sehingga tercipta motivasi dan minat untuk mempelajari bahasa Inggris secara mendalam. 
Untuk menjawab permasalahan-permasalahan di atas, perlu adanya penerapan model perkuliahan yang sesuai untuk meningkatkan kompetensi berbicara aktif (active speaking) mahasiswa PGSD yaitu dengan menerapkan model pembelajaran Communicative Language Teaching (CLT) pada mata kuliah bahasa Inggris di jurusan PGSD yang berbasis nilai-nilai karakter. Melalui penerapan model pembelajaran CLT ini yang berbasis nilai-nilai karakter, diharapkan kompetensi mahasiswa PGSD dalam berbicara bahasa Inggris secara aktif (active speaking) dapat meningkat secara signifikan, sekaligus mereka memiliki nilai-nilai karakter berbahasa dan bersikap yang luhur.

Peneliti membatasi lingkup penelitian ini pada dua hal. Pertama, penelitian ini hanya akan dibatasi pada masalah kompetensi berbicara aktif (active speaking) melalui penerapan model pembelajaran communicative language teaching yang berbasis nilainilai karakter dengan memberikan latihan-latihan atau tugas-tugas yang relevan untuk meningkatkan keterampilan berbicara (speaking). Kedua, dari 8 kelas yang ada, penelitian ini difokuskan hanya pada satu kelas yaitu kelas F semester 1 agar penelitian lebih mendalam. Hal ini juga didukung oleh fakta bahwa mata kuliah bahasa Inggris di PGSD Unnes diajarkan pada semester pertama.

Berdasarkan pada uraian-uraian tersebut di atas, masalah dalam penelitian ini dapat diformulasikan sebagai berikut: (1) bagaimana meningkatkan kompetensi berbicara aktif (active speaking) mahasiswa PGSD UUNES melalui penerapan model pembelajaran communicative language teaching (CLT) pada mata kuliah bahasa Inggris yang berbasis nilai-nilai karakter berbahasa; dan (2) sejauh mana penerapan model pembelajaran communicative language teaching (CLT) pada mata kuliah bahasa Inggris yang berbasis nilai-nilai karakter dapat meningkatkan kompetensi berbicara aktif (active speaking) mahasiswa PGSD.

Tujuan umum penelitian ini yaitu (a) untuk mengetahui penerapan model pembelajaran communicative language teaching (CLT) dalam meningkatkan kompetensi berbicara aktif (active speaking) mahasiswa PGSD pada mata kuliah 
bahasa Inggris yang berbasis nilai-nilai karakter di PGSD UNNES, dan (b) mengetahui sejauh mana penerapan model pembelajaran communicative language teaching (CLT) yang berbasis nilai-nilai karakter dapat meningkatkan kompetensi berbicara aktif (active speaking) mahasiswa PGSD pada mata kuliah bahasa Inggris di PGSD UNNES.

Secara khusus, penelitian ini bertujuan untuk mengkaji tujuan perkuliahan, nilai-nilai karakter berbahasa, materi perkuliahan, kegiatan belajar mengajar, peran dosen, peran mahasiswa, dan evaluasi yang dianggap merupakan bagian dari proses KBM yang sangat penting.

Peneliti juga mengkaji pengaruh penerapan model pembelajaran communicative language teaching (CLT) dalam perkuliahan bahasa Inggris di PGSD yang berbasis nilai-nilai karakter terhadap kemampuan active speaking mahasiswa PGSD dilihat dari hasil pembelajaran mahasiswa yang diwakili oleh nilai kemampuan mereka dalam berbicara aktif (active speaking).

\section{B. METODE PENELITIAN.}

Penelitian ini dilaksanakan di Jurusan Pendidikan Guru Sekolah Dasar (PGSD kampus Semarang) Fakultas Ilmu Pendidikan (FIP) Universitas Negeri Semarang (UNNES), dimana mata kuliah Bahasa Inggris merupakan mata kuliah wajib yang harus ditempuh oleh setiap mahasiswa di semester pertama.

Pelaksanaan penelitian berlangsung lima bulan yaitu dari bulan AgustusNovember 2018. Penelitian dilakukan di rombel F S1 PGSD FIP dengan jumlah mahasiswa empat puluh orang.

Penelitian ini bersifat deskriptif kualitatif, yang mengkaji sesuatu secara empirik, yang dapat digolongkan ke jenis penelitian tindakan kelas (classroom action research). Dalam prosesnya, peneliti terlibat dalam pelaksanaan tindakan, mengamati, mencatat, dan merekam fakta yang terjadi selama meneliti. Alasan pemilihan pendekatan penelitian ini adalah bahwa pada jenis penelitian kualitatif melakukan pengkajian pada latar alamiah atau pada konteks dari suatu keutuhan (entity). Konteks yang dimaksud adalah proses KBM bahasa Inggris dengan penerapan model CLT yang

70 MAGISTRA - Volume 9 Nomor 2 Desember 2018 
dilaksanakan oleh dosen dan mahasiswa. Kemudian yang dimaksud latar alamiah adalah ruang kelas di PGSD, sebagai tempat pelaksanaan proses KBM seperti apa adanya tanpa rekayasa.

Jenis penelitian yang akan digunakan adalah penelitian tindakan kelas, yang terdiri dari beberapa siklus. ${ }^{2}$ Setiap siklus terdiri dari 4 tahapan kegiatan yaitu perencanaan (planning), tindakan (acting), pengamatan (observing) dan refleksi (reflecting). Pelaksanaan dari siklus-siklus penelitian ini akan berakhir bila telah mencapai target yang dikehendaki, yaitu kemampuan komunikatif mahasiswa dalam active speaking mencapai nilai rata-rata 73 (kriteria baik). Alur penelitian tindakan kelas yang akan dilaksanakan seperti dalam gambar 1 berikut ini:

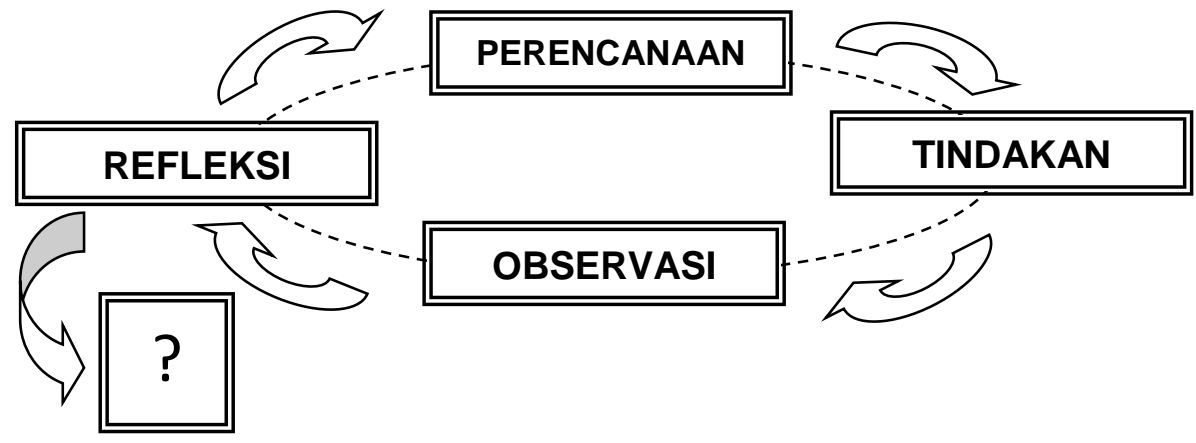

Gambar 1. Alur Penelitian Tindakan Kelas ${ }^{3}$

${ }^{2}$ Suharsimi Arikunto, Penilaian Program Pendidikan, Jakarta: Proyek Pengembangan Lembaga Pendidikan

71 MAGISTRA - Volume 9 Nomor 2 Desember 2018 
Secara detail alur penelitian tindakan kelas digambarkan seperti pada gambar 2 sebagai berikut:

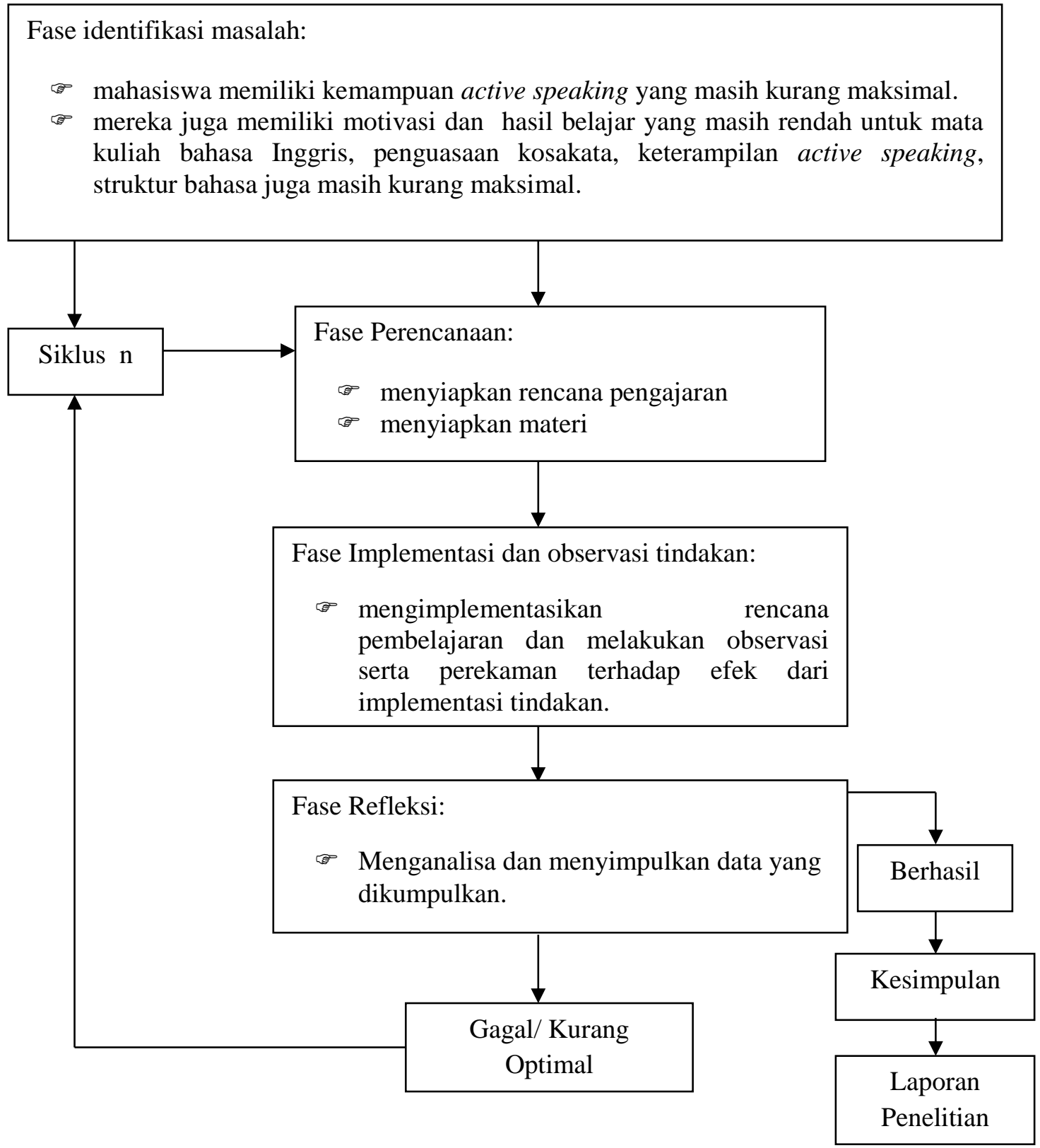

Langkah-langkah yang dilakukan pada siklus pertama yaitu sebagai berikut: perencanaan mencakup langkah-langkah sebagai berikut: (i) persiapan pembelajaran, berupa pembuatan satuan pembelajaran dan rencana pembelajaran, pemilihan sumber 
belajar yang akan digunakan sebagai materi; (ii) pengadaan media seperti video recorder, televisi, video player dan video compact disc; dan (iii) pengadaan instrumen observasi, seperti jurnal penelitian dan pedoman wawancara.

Pelaksanaan tindakan dilakukan berupa pertemuan di kelas dan yang bertindak sebagai implementer adalah pengajar-peneliti. Tindakan dilakukan sesuai dengan langkah-langkah yang telah direncanakan, seperti tercantum pada satuan dan rencana pembelajaran. Langkah-langkah tersebut adalah (1) memperkenalkan dan mendemonstrasikan penggunaan metode pembelajaran baru secara lisan dan contohnya melalui audio video recording (audio-visual aids) dan diskusi, (2) mendiskusikan bagaimana metode pembelajaran tersebut dilakukan secara sistematis, (3) berlatih untuk menggunakan metode pembelajaran baru tersebut yang baru dipelajari, (4) menjelaskan dan menyuruh mahasiswa untuk mensimulasi metode pembelajaran baru tersebut bersama dengan mahasiswa lain secara kolaboratif sesuai dengan topik bahasan, (5) melaporkan hasil yang mereka dapatkan di depan kelas, dan (6) memberikan umpan balik tentang kelebihan dan kekurang mahasiswa dalam pelaporan dengan memutar kembali hasil rekaman presentasi mereka. ${ }^{3}$

Pengamatan dilakukan dalam rangka mengumpulkan data-data yang diperlukan untuk mengetahui kinerja siklus. Jurnal peneliti dan perekam video digunakan untuk mengambil data yang berhubungan dengan proses belajar-mengajar, tes (dalam bentuk presentasi task) yang dikombinasikan dengan penggunaan perekam video juga digunakan untuk mengetahui keterampilan mahasiswa dalam presentasi di depan kelas. Terakhir, pedoman wawancara juga diterapkan pada setiap akhir siklus untuk mengetahui respon, perasaan dan juga untuk mengumpulkan berbagai saran dari mahasiswa demi penyempurnaan proses belajar-mengajar.

Hal pertama yang perlu dilakukan pada fase refleksi ini adalah menganalisis data yang ditemukan melalui fase pengamatan. Dalam hal ini, data yang didapatkan melalui speech presentation mahasiswa dibahas secara deskriptif dengan memberikan

${ }^{3}$ Samana, A. Profesionalisme Keguruan, Yogyakarta : Kanisius, 2014.

73 MAGISTRA - Volume 9 Nomor 2 Desember 2018 
skor atau nilai kuantitatif. Data yang lain yang didapat dari jurnal peneliti dan handycam, dan pedoman wawancara dianalisis secara deskriptif kualitatif dalam bentuk paparan yang terorganisasi dengan mengikuti prosedur analisis data deskriptif kualitatif, seperti (1) tabulasi data, (2) reduksi data melalui pengkategorian, (3) interpretasi, dan (4) pengambilan simpulan. Fase berikutnya yang perlu dilakukan setelah data dianalisis adalah menyimpulkan data tersebut. Melalui simpulan ini, kelebihan dan kelemahan kinerja siklus dapat diketahui. Hasil refleksi siklus pertama ini digunakan sebagai acuan untuk langkah-langkah berikutnya pada siklus II.

Subyek penelitian meliputi dosen bahasa Inggris dan mahasiswa PGSD. Jumlah dosen yang mengajar bahasa Inggris di PGSD adalah 2 orang dan jumlah kelas keseluruhan untuk setiap angkatan adalah delapan kelas. Namun, penelitian ini hanya diadakan di satu kelas (kelas F) dengan jumlah mahasiswa sebanyak 38 orang.

Teknik pengumpulan data yang digunakan dalam penelitian ini ada empat jenis, yaitu pengamatan, wawancara, kuesioner, dan analisis dokumen. Teknik pengamatan didasarkan atas pengamatan secara langsung yang memungkinkan peneliti bisa melihat, mengamati, dan kemudian mencatat perilaku dan kejadian sebagaimana yang terjadi pada keadaan yang sebenarnya. Teknik pengamatan juga memungkinkan peneliti mampu memahami situasi-situasi yang rumit. Berikut ini contoh lembar pengamatan untuk penilaian kemampuan berbicara aktif (active speaking) mahasiswa: 
Tabel 1. Pengamatan Kemampuan berbicara aktif

\begin{tabular}{|c|c|c|c|}
\hline No & ASPEK & SKOR & KETERANGAN \\
\hline \multirow[t]{5}{*}{1} & \multirow{5}{*}{$\begin{array}{l}\text { Pengucapan Kata } \\
\text { (Pronunciation) }\end{array}$} & 5 & Mudah dipahami dan memiliki aksen penutur asli \\
\hline & & 4 & Mudah dipahami meskipun dengan aksen tertentu \\
\hline & & 3 & $\begin{array}{l}\text { Ada masalah pengucapan yang membuat pendengar harus } \\
\text { konsentrasi penuh dan kadang-kadang ada kesalahpahaman }\end{array}$ \\
\hline & & 2 & $\begin{array}{l}\text { Sulit dipahami karena ada masalah pengucapan, sering } \\
\text { diminta mengulang }\end{array}$ \\
\hline & & 1 & Masalah pengucapan serius sehingga tidak bisa dipahami \\
\hline \multirow[t]{5}{*}{2} & \multirow{5}{*}{$\begin{array}{l}\text { Tata Bahasa } \\
\text { (Grammar) }\end{array}$} & 5 & Tidak ada atau sedikit kesalahan tata bahasa \\
\hline & & 4 & $\begin{array}{l}\text { Kadang-kadang membuat kesalahan tata bahasa tetapi tidak } \\
\text { mempengaruhi makna }\end{array}$ \\
\hline & & 3 & $\begin{array}{l}\text { Sering membuat kesalahan tata bahasa yang mempengaruhi } \\
\text { makna }\end{array}$ \\
\hline & & 2 & $\begin{array}{l}\text { Banyak kesalahan tata bahasa yang menghambat makna dan } \\
\text { sering menata ulang kalimat }\end{array}$ \\
\hline & & 1 & Kesalahan tata bahasa begitu parah sehingga sulit dipahami \\
\hline \multirow[t]{5}{*}{3} & \multirow{5}{*}{$\begin{array}{l}\text { Kosakata } \\
\text { (Vocabulary) }\end{array}$} & 5 & Menggunakan kosa kata dan ungkapan seperti penutur asli \\
\hline & & 4 & Kadang-kadang menggunakan kosa kata yang tidak tepat \\
\hline & & 3 & $\begin{array}{l}\text { Sering menggunakan kosa kata yang tidak tepat, percakapan } \\
\text { menjadi terbatas karena keterbatasan kosa kata }\end{array}$ \\
\hline & & 2 & $\begin{array}{l}\text { Menggunakan kosa kata secara salah dan kosa kata terbatas } \\
\text { sehingga sulit dipahami }\end{array}$ \\
\hline & & 1 & $\begin{array}{l}\text { Kosa kata sangat terbatas sehingga percakapan tidak mungkin } \\
\text { terjadi }\end{array}$ \\
\hline \multirow[t]{5}{*}{4} & \multirow{5}{*}{$\begin{array}{l}\text { Kelancaran } \\
\text { (Fluency) }\end{array}$} & 5 & Lancar seperti penutur asli \\
\hline & & 4 & Kelancaran tampak sedikit terganggu oleh masalah bahasa \\
\hline & & 3 & Kelancaran agak banyak terganggu oleh masalah bahasa \\
\hline & & 2 & Sering ragu-ragu dan terhenti karena keterbatasan bahasa \\
\hline & & 1 & $\begin{array}{l}\text { Bicara terputus-putus dan terhenti sehingga percakapan tidak } \\
\text { mungkin terjadi }\end{array}$ \\
\hline \multirow[t]{5}{*}{5} & \multirow{5}{*}{$\begin{array}{l}\text { Pemahaman } \\
\text { (Comprehension) }\end{array}$} & 5 & Memahami semua tanpa mengalami kesulitan \\
\hline & & 4 & $\begin{array}{l}\text { Memahami hampir semuanya, walau ada pengulangan pada } \\
\text { bagian tertentu }\end{array}$ \\
\hline & & 3 & $\begin{array}{l}\text { Memahami sebagian besar apa yang dikatakan bila bicara } \\
\text { agak diperlambat walau ada pengulangan }\end{array}$ \\
\hline & & 2 & Susah mengikuti apa yang dikatakan. \\
\hline & & 1 & Tidak bisa memahami walaupun percakapan sederhana \\
\hline
\end{tabular}

Wawancara dilakukan oleh peneliti terhadap dosen dan mahasiswa. Wawancara dilaksanakan terhadap 1 dosen pengampu matakuliah bahasa Inggris dan mahasiswa 
PGSD semester 1 rombel 1 di mana penelitian dilaksanakan. Tujuannya adalah untuk memperoleh informasi tentang pemahaman mereka tentang CLT, penerapannya dalam perkuliahan bahasa Inggris, pengaruhnya terhadap hasil belajar mahasiswa, dan faktorfaktor yang menghambat penerapan CLT tersebut dalam pengajaran bahasa Inggris. Dalam wawancara tersebut semua dosen diberi pertanyaan yang sama dengan urutan yang sama. Peneliti akan menyebar 1 lembar kuesioner untuk dosen dan 38 kuesioner untuk mahasiswa. Dari jumlah kuesioner yang disebar, seluruh kuesioner diisi dan dikembalikan kepada peneliti.

Kuesioner diberikan kepada dosen bahasa Inggris dan kepada semua mahasiswa semester 1F yang berjumlah 38 mahasiswa. Kuesioner untuk dosen berbeda dengan kuesioner untuk mahasiswa. Kuesioner untuk dosen berisi sepuluh pertanyaan tertutup (close-ended questions) dan tiga pertanyaan terbuka (open-ended questions), sedangkan kuesioner untuk mahasiswa berisi delapan pertanyaan tetutup (close-ended questions).

Dokumentasi dilakukan terhadap daftar nilai mahasiswa agar diketahui bagaimana hasil belajar mahasiswa yang belajar menggunakan CLT. Tujuan analisis dokumen ini adalah untuk melengkapi informasi yang telah diperoleh melalui pengamatan dan wawancara.

Peneliti mengumpulkan dokumen nilai bahasa Inggris yakni nilai pre-test dan nilai post-test. Untuk mendapatkan data penelitian yang kredibel atau sahih yang dapat digunakan untuk menarik kesimpulan, data diperiksa dulu kredibilitasnya. Pemeriksaan kredibilitas data dilakukan dengan ketekunan pengamatan dan triangulasi ${ }^{4}$

Teknik yang digunakan dalam penelitian ini adalah ketekunan pengamatan dan triangulasi. Data yang didapat adalah data hasil wawancara, hasil pengamatan, kuesioner, dan data nilai mahasiswa.

Proses analisis data ini tidak dilakukan hanya setelah semua data terkumpul, melainkan akan dilaksanakan sejak awal pengumpulan data dan dikerjakan secara intensif setelah proses pengambilan data di lapangan. Pemilahan data pun dilakukan

\footnotetext{
${ }^{4}$ Lexy J Moleong, Metodologi penelitian kualitatif, Bandung: PT. Remaja Rosdakarya, 2010
}

76 MAGISTRA - Volume 9 Nomor 2 Desember 2018 
sesuai dengan kategorinya, misalnya data tentang peran dosen dan peran mahasiswa dibedakan pencatatannya. Proses analisis data akan berlangsung melalui kegiatan refleksi, mereduksi data, menampilkan data, dan verifikasi untuk menarik kesimpulan seluruh data yang tersedia di baca, dipelajari, dan ditelaah kemudian diadakan reduksi data yang dilakukan dengan jalan membuat abstraksi. Abstraksi merupakan usaha membuat rangkuman yang inti, proses dan pernyataan yang perlu dijaga sehingga tetap berada di dalamnya.

Langkah berikutnya yaitu penyusunan dalam satuan-satuan informasi, sesuai dengan kategorinya. Kategori itu dilakukan sambil membuat pengkodean (coding). Tahap akhir dari analisis data ini adalah mengadakan pemeriksaan kesahihan data dengan teknik-teknik seperti diuraikan di atas. Setelah selesai tahap ini dilakukan penafsiran data untuk menarik kesimpulan atau verifikasi.

Satuan informasi tidak lain adalah bagian terkecil yang mengandung makna yang bulat dan dapat berdiri sendiri terlepas dari bagian yang lain ${ }^{6}$. Satuan informasi ditemukan dalam catatan lapangan, catatan wawancara, catatan pengamatan dan dokumen. Misalnya, dalam catatan lapangan, peneliti mencatat bahwa dosen menjelaskan cara mengerjakan tugas sebagai pelaksanaan perannya sebagai dosen bahasa Inggris. Hal itu dapat disebut sebagai suatu satuan. Satuan informasi demi satuan informasi demikian dikelompokkan menjadi satu kategori, yaitu kategori peran dosen.

\section{HASIL DAN PEMBAHASAN}

Penelitian ini dilaksanakan di kelas/rombel F Program Studi Pendidikan Guru Sekolah Dasar (PGSD) FIP UNNES yang berlokasi di kampus Semarang, Jl. Beringin Raya 15 Wonosari Ngaliyan Semarang. Hal ini dilakukan karena berdasarkan hasil observasi awal yang dilakukan oleh peneliti, kelas tersebut memiliki prestasi belajar bahasa Inggris yang relatif bagus secara Passive English terutama dalam penguasaan grammar atau structure tapi kurang secara Active English yaitu dalam penguasaan 
berbicara aktif (Active Speaking) dalam pembelajaran bahasa Inggris. Subjek penelitian ini adalah seluruh mahasiswa di rombel 1F yang berjumlah 38 orang mahasiswa.

Obyek penelitian ini adalah kemampuan berbicara aktif (Active Speaking) mahasiswa dalam perkuliahan bahasa Inggris di PGSD Unnes. Minimnya kemampuan active speaking mahasiswa PGSD Unnes bisa disebabkan oleh proses pembelajaran bahasa Inggris pada tingkat pendidikan sebelumya, baik di tingkat SLTA maupun SLTP, dimana pembelajaran bahasa Inggris yang dilaksanakan di tingkat SLTA dan SLTP kurang optimal mengembangkan kemampuan berbicara aktif (active speaking). Pembelajaran lebih difokuskan pada materi dan penguasaan passive English yaitu materi pada tataran tata bahasa. Hal demikian dapat tampak dari hasil kemampuan tes speaking bahasa Inggris mahasiswa yang sebagian besar masih rendah. Secara umum, hasil tes awal tersebut dapat ditampilkan dalam tabel berikut:

Tabel 2. Hasil Tes Awal Kemampuan Speaking Mahasiswa

\begin{tabular}{|l|r|c|c|l|}
\hline Nilai & Kategori & Frekuensi & $\begin{array}{c}\text { Persentase } \\
(\boldsymbol{\%})\end{array}$ & \multicolumn{1}{|c|}{ Kategori Kurang dan Gagal } \\
\hline $86-100$ & Sangat Baik & 2 & 5,26 & Nilai speaking kategori kurang dan \\
\hline $71-85$ & Baik & 5 & 13,16 & gagal sebesar 50,02\% \\
\hline $61-70$ & Cukup & 12 & 31,58 & \\
\hline $51-60$ & Kurang & 18 & 47,39 & \\
\hline $01-50$ & Gagal & 1 & 2,63 & \\
\hline & Jumlah & 38 & $100 \%$ & \\
\hline
\end{tabular}

Berdasarkan observasi awal diperoleh informasi bahwa kemampuan speaking mahasiswa masih kurang aktif sekali, sebagaimana terlihat pada tabel 3. Salah satu penyebabnya adalah model pembelajaran mahasiswa yang lebih difokuskan pada tataran kemampuan tata bahasa, sehingga model pembelajaran bahasa Inggris yang kurang aktif tersebut berpengaruh pada kemampuan berbicara aktif (Active Speaking). Dilihat dari kondisi awal dapat terlihat bahwa kemampuan berbicara aktif (Active Speaking) mahasiswa masih rendah, hanya 18,42\% mahasiswa yang kemampuan 
berbicara aktif (Active Speaking) dalam kategori baik atau sangat baik.

Pelaksanaan siklus I dapat diperoleh data bahwa pengetahuan dosen tentang model communicative language teaching sudah cukup baik, hal ini disebabkan karena dosen telah melaksanakan beberapa penelitian tentang communicative competence terutama dalam konteks pengajaran bahasa Inggris. Proses pembelajaran siklus I lebih terfokus pada tahapan performance phase, yaitu mahasiswa mempresentasikan kemampuan speaking secara individu, sehingga sesuai dengan karakteristiknya, bahwa model communicative language teaching ini memang lebih cenderung student centered dimana mahasiswa harus lebih aktif dan memiliki partisipasi lebih dalam proses KBM.

Dari hasil pengamatan pada kondisi awal dapat dikatakan bahwa kemampuan berbicara aktif (active speaking) mahasiswa masih rendah. Pada pertemuan pertama siklus I, kemampuan speaking mahasiswa mulai ada peningkatan. Hal ini karena mahasiswa harus mempresentasikan task self introduction secara individu di depan kelas sehingga mereka berlatih sebelumnya. Hal ini memberikan motivasi kepada mahasiswa untuk gita berlatih dan meningkatkan self motivation dan self confidence, dan kedua hal tersebut sangat berguna dalam peningkatan kemampuan speaking secara aktif.

Kemampuan berbicara aktif (active speaking) mahasiswa diukur dengan menggunakan lembar penilaian proses. Aspek berbicara aktif (active speaking) yang dinilai mencakup aspek penguasaan tata bahasa, kelancaran, ketepatan, penguasaan kosakata dan isi. Adapun prestasi belajar siswa dalam siklus I ini disajikan dalam tabel dibawah ini. Dilihat dari hasil penilaian siklus I ada peningkatan rara-rata kelas. Nilai rata-rata kelas pada pra tindakan yaitu 68,77 pada siklus I meningkat menjadi 76,38. Secara garis besar hasil data tersebut dapat disajikan dalam tabel dibawah ini.

Tabel 3. Rekapitulasi Hasil Nilai Siklus I

\begin{tabular}{||c|c|c|c|}
\hline Nilai & Nilai & Rerata & Tuntas \\
\hline Tertinggi & Terendah & & Belajar \\
\hline 90 & 62 & 76,38 & $62,70 \%$ \\
\hline
\end{tabular}

79 MAGISTRA - Volume 9 Nomor 2 Desember 2018 
Berdasarkan hasil penilaian kemampuan berbicara aktif (active speaking) pada siklus I menunjukkan sudah ada peningkatan. Dengan adanya tuntutan bahwa setiap mahasiswa harus mempresentasikan kemampuanya masing-masing maka mahasiswa termotivasi untuk tampil maksimal. Beberapa mahasiswa berlatih dan mempersiapkan dengan maksimal, sehingga dalam proses presentasi sangat terlihat ada peningkatan yang cukup signifikan. Dua hal yang perlu ditingkatkan dalam pertemuan selanjutnya, yaitu: (1) masih terdapat beberapa mahasiswa yang masih kurang percaya diri dalam mempresentasikan kemampuan berbicara aktif (active speaking). Hal ini karena kurangnya intensitas latihan sebelum tampil, maka dosen perlu memotivasi mahasiswa untuk lebih giat berlatih lagi, dan (2) masalah ketersediaan waktu untuk tampil, maka alokasi waktu untuk mahasiswa harus lebih proporsional agar bisa tampil lebih maksimal.

Pelaksanaan siklus II dapat diperoleh data tentang pengetahuan mengenai model communicative language teaching sudah baik, karena dosen telah melaksanakan beberapa penelitian tentang communicative competence. Pada siklus II, kompetensi yang dilakukan yaitu retelling story dan English for bilingual instruction, yang mana dosen tidak menemukan kendala-kendala berarti karena kedua task tersebut sesuai dengan model CLT. Fokus penelitian ini pada peningkatan kemampuan berbicara aktif (active speaking), maka dosen dalam pelaksanaan model CLT ini juga menerapkan teori implementasi pembelajaran 3 Muranoi's interaction enhancements.

Pada proses KBM siklus II kegiatan lebih fokus pada tahap performance phase, yaitu mahasiswa mempresentasikan kemampuan berbicara aktif (active speaking) secara perseorangan, sehingga metode communicative language teaching ini memang lebih cenderung student center dan sesuai dengan karakteristiknya, yaitu memfokuskan pada keaktifan mahasiswa secara maksimal. Kondisi dan suasana kelas mendukung sekali dalam penerapan model CLT ini bagi mahasiswa merupakan calon guru SD, sehingga task retelling story sesuai dengan kegiatan pembelajaran di SD nantinya yaitu dapat bercerita di depan kelas. Sedangkan task English for bilingual instruction sesuai 
dengan kebutuhan mahasiswa kelas, yaitu mengajar dengan menggunakan dua bahasa, khususnya bahasa Inggris sebagai medium of instructions.

Pada siklus II mahasiswa terlihat termotivasi dalam KBM ini. Berdasarkan pengamatan dan penilaian terhadap kemampuan berbicara aktif (active speaking), diketahui bahwa kemampuan mahasiswa dalam speaking mengalami peningkatan, khususnya pada aspek tata bahasa, kelancaran, pengucapan kata, ketepatan, kosakata, dibandingkan pada siklus I. Hal ini karena self motivation dan self confidence yang semakin meningkat berlatih pada siklus I. Pada pertemuan pertama siklus II, kemampuan berbicara aktif (active speaking) mahasiswa juga ada peningkatan. Hal ini karena adanya kebutuhan mahasiswa harus mempresentasikan task retelling story dan English for bilingul instructions, sehingga mahasiswa telah mempersiapkannya secara matang sebelumnya.

Untuk mengetahui kemampuan berbicara aktif (active speaking) mahasiswa, peneliti menggunakan lembar penilaian proses. Penilaian dilakukan pada saat mahasiswa mempresentasikan retelling story dan English for bilingual instructions di depan kelas secara individu. Penilaian tersebut untuk mengukur kemampuan berbicara aktif (active speaking) mahasiswa akan penguasaan pronunciation, accuracy, vocabulary, and contents. Hasil penilaian siklus II ada peningkatan nilai rata-rata kelas. Nilai rata-rata kelas pada siklus I yaitu 76,38 pada siklus I meningkat menjadi 82,20. Secara garis besar hasil data tersebut dapat disajikan dalam tabel 4 di bawah ini: Tabel 4. Rekapitulasi Hasil Nilai Siklus II

\begin{tabular}{||c|c|c|c|}
\hline Nilai & Nilai & Rerata & Tuntas \\
\hline Tertinggi & Terendah & & Belajar \\
\hline 95 & 74 & 82,20 & $78,50 \%$ \\
\hline
\end{tabular}

Hasil penilaian kemampuan berbicara aktif (active speaking) pada siklus II tampak ada peningkatan yang cukup signifikan, karena adanya tindakan berupa task Retelling Story dan English for bilingual instructions. Seperti halnya dengan siklus I, adanya tuntutan bahwa setiap mahasiswa harus mempresentasikan kemampuan

81 MAGISTRA - Volume 9 Nomor 2 Desember 2018 
berbicara aktif (active speaking) maka mahasiswa termotivasi untuk tampil optimal, mereka berlatih sebelumnya secara maksimal, sehingga proses presentasi ada peningkatan kualitas yang signifikan.

Fokus penelitian ini yaitu untuk meningkatkan kemampuan berbicara aktif (active speaking), maka peneliti menerapkan teori implementasi pembelajaran 3 Muranoi's interaction enhancements yang dikutip dalam Doughty and Williams (1998) pada siklus I dan II, yaitu: tahap (1) rehearsal phase, tahap (2) performance phase, dan

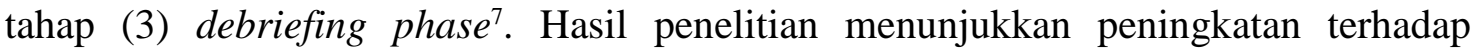
kemampuan berbicara aktif (active speaking) mahasiswa. Hasil Rerata kelas sebelum tindakan yaitu 68,77. Pada siklus I ketuntasan belajar sebesar 66,70\%. Pada siklus II rata-rata kelas meningkat menjadi 82,20 dan ketuntasan belajar sebesar 78,50\%.

Penelitian ini juga menemukan nilai-nilai karakter yang muncul dari pra siklus, hingga siklus kedua yaitu, beriman dan bertakwa, jujur, cerdas, tangguh, peduli, demokratis, komunikatif, saling menghargai, kerja sama, dan santun berbahasa. Berikut rangkuman tabel 5 tentang nilai-nilai karakter tersebut:

Tabel 5 Nilai Karakter yang diperoleh

\begin{tabular}{|c|l|c|c|}
\hline No & \multicolumn{1}{|c|}{ Nilai Karakter } & Rata-rata Skor & Keterangan \\
\hline 1 & Beriman dan bertakwa & 83 & Baik \\
\hline 2 & Jujur & 80 & Baik \\
\hline 3 & Cerdas & 78 & Baik \\
\hline 4 & Tangguh & 78 & Baik \\
\hline 5 & Peduli & 77 & Baik \\
\hline 6 & Komunikatif & 80 & Baik \\
\hline 7 & Demokratis & 81 & Baik \\
\hline 8 & Kerjasama & 79 & Baik \\
\hline 9 & Saling menghargai & 81 & Baik \\
\hline 10 & Santun (berbahasa) & 79,7 & Baik \\
\hline & Rata-rata Skor Keseluruhan & & \\
\hline
\end{tabular}

Berdasarkan hasil analisis data, diperoleh fakta bahwa mahasiswa PGSD Unnes yang sedang mengambil mata kuliah Bahasa Inggris memiliki nilai karakter dan berbahasa yang bagus. Hal ini ditunjukkan dengan pemerolehan skor rata-rata sebesar 
79,7 dengan kategori baik. Data tersebut menunjukan bahwa secara umum mahasiswa memiliki dan sudah mengimplementasikan nilai-nilai karakter beriman dan bertakwa, jujur, cerdas, tangguh, peduli, demokratis, komunikatif, saling menghargai, kerja sama, dan santun berbahasa dalam kehidupannya sehari-hari terutama di lingkungan kampus.

Berdasarkan hasil penelitian telah terbukti bahwa model CLT dapat sebagai salah satu model pembelajaran yang dapat meningkatkan kemampuan berbicara aktif (active speaking) mahasiswa secara signifikan, kendatipun pada pelaksanaan siklus I masih terdapat kekurangan, akan tetapi model tersebut tetap dapat meningkatkan kemampuan berbicara aktif (active speaking), serta dapat pula meningkatkan aspek self motivation dan self confidance mahasiswa. Peningkatan-peningkatan tersebut tampak signifikan pada siklus II, karena adanya refleksi dan perbaikan dari siklus I. Nilai kompetensi berbicara aktif (active speaking) mahasiswa juga meningkat di setiap siklus.

Berdasarkan data hasil capaian penelitian di siklus I dan II, dapat disimpulkan bahwa model CLT dapat meningkatkan kemampuan berbicara aktif (active speaking), disamping dapat pula meningkatkan motivasi dan kepercayaan diri mahasiswa dalam berbicara aktif (active speaking) dalam bahasa Inggris lebih optimal. Hal ini sesuai dengan teori communicative competence yang mengkombinasikan ke empat kompetensi yaitu grammatical competence, socilinguistic competence, discourse competence, dan strategic competence. Penggabungan dan kombinasi dari keempat kompetensi tersebut dapat memotivasi mahasiswa untuk mampu menggali potensi mereka secara maksimal, dari aspek motivasi, kepercayaan diri, dan prestasi belajar. Berdasarkan hasil temuan pada penelitian ini, dan pembahasan, maka dapat dinyatakan bahwa model Communicative Language Teaching (CLT) secara signifikan dapat meningkatkan kemampuan berbicara aktif (active speaking) mahasiswa PGSD UNNES pada mata kuliah bahasa Inggris.

Di samping itu, terkait dengan pembelajaran bahasa Inggris, mahasiswa wajib sadar pentingnya penguasaan dan penggunaan bahasa Inggris yang tepat karena bahasa 
sebagai jembatan penghubung dengan orang lain dan dunia lain. Dengan berbahasa yang beretika, dan bernuansa nilai-nilai karakter berbahasa akan membuat orang lain merasa nyaman dalam berkomunikasi atau menempatkan diri dalam berkomunikasi, menjadi syarat mutlak untuk terjadinya sopan-santun dalam berbahasa. Sebagai mahasiswa tentu hal ini penting diperhatikan sebagai wujud implementasi bahasa yang berkarakter.

\section{SIMPULAN}

Berdasarkan capaian hasil penelitian dan pembahasan, dapat disimpulkan bahwa penerapan model Communicative Language Teaching (CLT) terbukti dapat meningkatkan kemampuan berbicara aktif (active speaking) dalam perkuliahan bahasa Inggris, khususnya bagi mahasiswa PGSD UNNES. Hal ini karena implementasi atau penerapan model CLT memiliki kelebihan dalam meningkatkan berbicara aktif (active speaking) diantaranya yaitu dapat meningkatkan motivasi diri (self motivation) dan kepercayaan diri (self confidence). Peningkatan aspek motivasi diri (self motivation) dan kepercayaan diri (self confidence) dapat menyebabkan peningkatan peran aktif mahasiswa dalam aspek motorik yaitu mempresentasikan kemampuan motivasi diri (self motivation) dan kepercayaan diri (self confidence) di depan kelas secara individu. Hal tersebut menuntut mahasiswa untuk dapat berfikir dan bertindak secara optimal.

Berdasarkan simpulan di atas, maka saran-saran yang dapat disampaikan oleh peneliti sebagai berikut: (1) dosen bahasa Inggris PGSD perlu lebih memahami dan mengkaji lebih menalam tentang model CLT, sehingga dapat mengimplementasikan model tersebut secara optimal untuk meningkatkan kemampuan active speaking, self motivation dan self confidence mahasiswa, (2) dosen bahasa Inggris PGSD UNNES sekiranya perlu membuat materi/bahan ajar mata kuliah bahasa Inggris yang dapat dilakukan dengan mengimplementasikan model CLT.

Kemampuan berbicara aktif (active speaking) sangat vital dalam komunikasi berbahasa Inggris, maka mahasiswa disarankan untuk senantiasa memotivasi diri, berlatih aktif bicara dalam bahasa Inggris dan berpartisipasi aktif dalam proses 
perkuliahan bahasa Inggris di kelas. Model pembelajaran CLT adalah salah satu model alternatif perkuliahan yang dapat diimplementasikan untuk meningkatkan motivasi diri (self motivation) dan kepercayaan diri (self confidence) $d$ an berbicara aktif (active speaking) mahasiswa dalam belajar bahasa Inggris. 


\section{DAFTAR PUSTAKA}

Arikunto, Suharsimi, Penilaian Program Pendidikan. Jakarta: Proyek Pengembangan Lembaga Pendidikan Tenaga Kepandidikan Direktorat Jenderal Pendidikan Tinggi Depdikbud, 2012.

Departemen Pendidikan Nasional. (2003). Kurikulum 2000 Standar Kompetensi Bahasa Inggris Sekolah Menengah Atas dan MA. Jakarta: Depdiknas, 2003.

Moleong, L. J, Metodologi Penelitian Kualitatif. Bandung: PT. Remaja Rosdakarya, 2010 .

Designing Task for the Communicative Classroom. Cambridge: Cambridge University Press, 2009.

2010.

, Task-based Language Teaching. Cambridge: Cambridge University Press, . Tak-Based Language Teaching in the Asia Context: Defining Task. Diambil pada tanggal 14 September 2007 dari http:///www.asian-efl.journal.com.

Nurgiyantoro, Burhan, Penilaian dalam Pengajaran Bahasa dan Sastra. Yogyakarta: BPFE, 2011.

Oemar Suwito, Komunikasi untuk Pembelajaran. Jakarta : Depdikbud, 2009.

Raka Joni, T, Pendekatan Cara Belajar Siswa Aktif: Acuan Konseptual Peningkatan Mutu Kegiatan Belajar Mengajar. Jakarta: Konsorsium Ilmu Pendidikan Depdikbud, 2009.

Rombepajung, J. P, Pengajaran dan Pembelajaran Bahasa Asing. Jakarta: Depdikbud, 2011.

Samana, A, Profesionalisme Keguruan. Yogyakarta: Kanisius, 2014.

Siswoyo, Bambang, Penerapan Pengajaran Berbasis Tugas dalam Pengajaran Bahasa Inggris dan Pengaruhnya terhadap Pembelajaran Siswa SLTP Negeri Karanganyar. Tesis magister, tidak diterbitkan. Universitas sebelas Maret. Surakarta, 2013. 
Soedjiarto. Memantapkan Sistem Pendidikan Nasional. Jakarta: Widiasarana Indonesia, 2013

Wahyuningsih, Tri. Peningkatan Pembelajaran Seni Tari melalui Penerapan Metode Imitatif dan Penugasan di SD Negeri Sidorejo, Selomartani, Kalasan, Sleman, Yogyakarta. Skripsi, tidak diterbitkan. Universitas Negeri Yogyakarta. Yogyakarta, 2015. 